\title{
The role of geochemistry in environmental and epidemiological studies in developing countries
}

\author{
British Geological Survey, Keyworth, Nottingham, United Kingdom, NG12 5GG
}

The effects of chemicals in the environment on the health of man and animals are a matter of increasing public concern. Many developing countries are particularly liable to trace-element toxicities and deficiencies because of local geological, climatic and socio-economic conditions, and these problems are now compounded by the consequences of land degradation, pollution, urbanisation and industrialisation resulting from rapid economic and population growth.

Recent work by the British Geological Survey illustrates the value of geochemistry in identifying environmental and health problems resulting from trace-element imbalances or contamination and in formulating strategies to reduce their impact.

An integrated and effective approach to these problems requires (1) the availability worldwide of regional geochemical data to the standards recommended by the IUGS Working Group on Global Geochemical Baselines and (2) a thorough understanding of the behaviour of the chemical elements in the environment and their pathways from rocks and soils to crops, animals and man.
It has long been known that the distribution of chemical substances in the environment can influence animal and human health, and this has become a subject of increasing public concern in recent years. In industrialised countries, concern is focused on accumulations of potentially harmful elements (PHEs) such as arsenic, cadmium, mercury and lead (see Figure 1), and on organic compounds such as DDT, PCBs and dioxins. Some of these chemicals may be classified as carcinogens, neurotoxins or irritants; others may cause reproductive failure or birth defects (World Health Organisation, 1988). It is also known that deficiencies in the essential trace elements cobalt, copper, zinc, selenium and iodine may have harmful effects on domestic livestock (Mertz, 1986), but comparable conditions in humans in developed countries are rare, since diets are diverse and generally provide adequate trace-element levels.

Regional geochemical data for developed countries have shown that relatively high concentrations of trace elements may occur as a result of natural processes, or as a consequence of human activity, or from a combination of the two (e.g. British Geological Survey, 1978-97; Appleton, 1992). Extensive regions have also been shown to have levels of essential trace elements well below those recommended for soils and pasture (Webb, 1964; Darnley et al., 1995). Excellent epidemiological data are available for some countries, and certain associations between environmental geochemistry, diet and degenerative disease have been suggested (e.g. Martyn et al., 1989). Variations in the trace-element status of crops reflect that of the soil in which they are grown, but this will have little effect on humans in developed countries where a normal diet will include food from different areas.

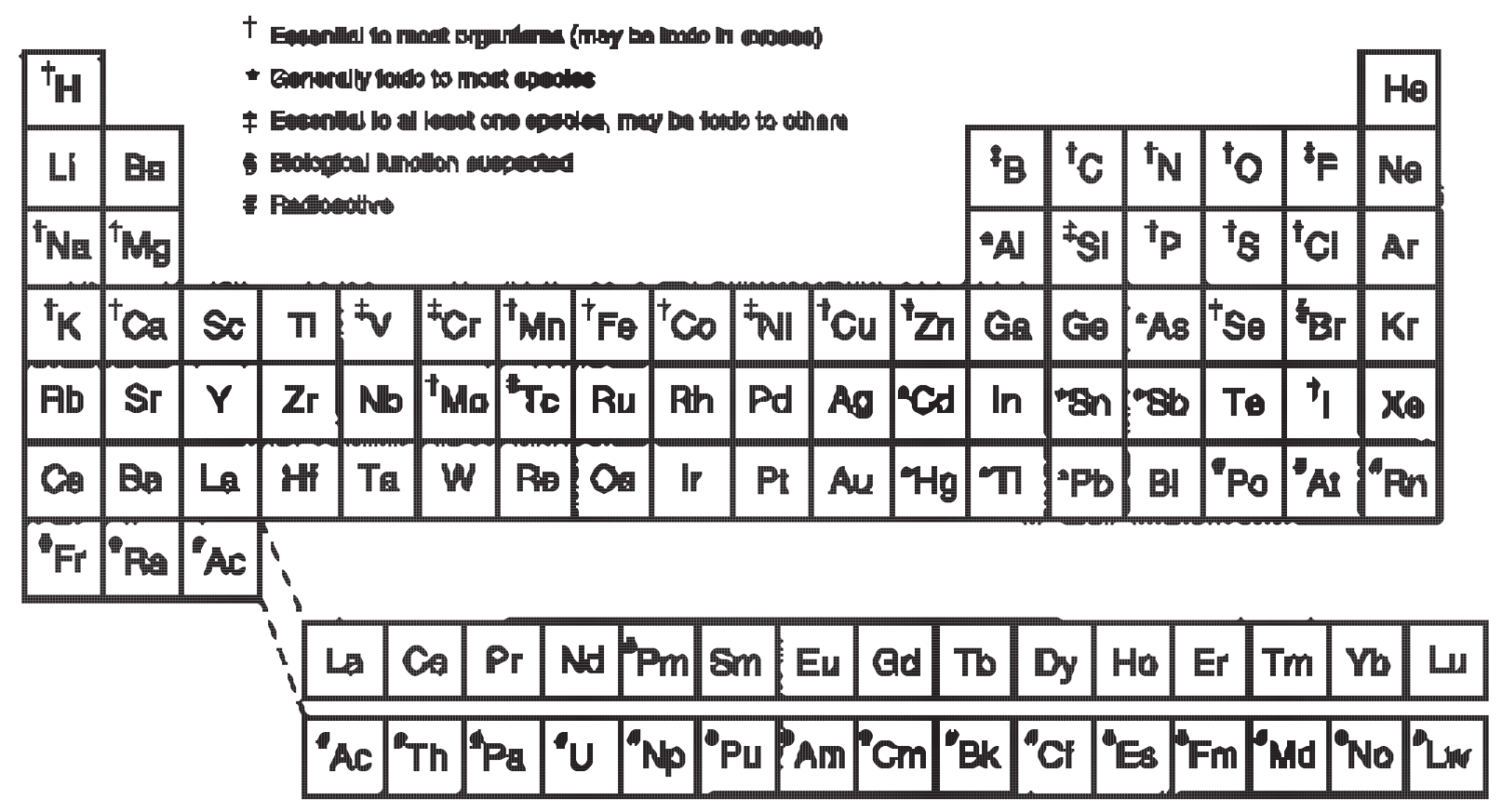

Figure 1 Periodic table, showing elements with known and possible biological effects (recently updated by $N$ Breward) 
By contrast, people living on subsistence agriculture in developing countries obtain much of their food from local sources, and trace-element deficiencies or toxicities may be much more critical for human health. Studies of the relationship between environmental geochemistry and health are therefore likely to be of more immediate importance in developing than developed countries. Unfortunately, modern geochemical data are rarely available for developing countries, or may be inadequate for environmental purposes, having been collected principally for mineral exploration.

In this paper we first briefly review the socio-economic threats to the environment of developing countries, with particular reference to the problems of tropical terrains. The basic requirements for preparing baseline geochemical data are described with reference to the guidelines developed by the International Geological Correlation Programme (IGCP) Projects 259 and 360 (Darnley et al., 1995), and the geochemical factors affecting the pathways of chemical elements from soils and water to plants, animals and man are discussed. The use of geochemical techniques in identifying potential problems and in developing amelioration strategies to reduce the impacts of industrial and agricultural activity are illustrated by recent studies carried out by the British Geological Survey (BGS) in developing countries.

\section{Socio-economic pressures on the environment of developing countries}

The annual increase in world population is approaching 100 million (United Nations Department of International Economic and Social Affairs, 1992). Approximately $90 \%$ of this is in the poorest countries, where one-quarter of the population live in 'absolute poverty' (having an annual income below US\$450) as defined by the World Bank (1992). Population pressure and poverty have adverse and inter-related impacts on the environment (McMichael, 1993). For example, the effects of large-scale coal burning in industrialising developing countries, increasing rice-field methane emission and widespread deforestation can all be attributed to population pressure. Problems associated with the use of marginal farmlands, soil erosion from cash cropping, uncontrolled industrial and urban pollution and the accumulation of potentially harmful wastes also cause problems in some developing countries (McMichael, 1993).

Each year about 6 million hectares of the world's agricultural land is lost through soil degradation (United Nations Department of International Economic and Social Affairs, 1992). Soil is a complex mixture of rock and mineral detritus, organic matter, microbes (bacteria, yeasts and fungi) and invertebrates. The removal of protective plant cover, overgrazing or overcropping leading to the depletion of essential nutrients, the addition of toxic chemicals, salination (in some areas as a result of irrigation) and acidification from power generation and industrialisation, can all cause soil organisms to die, leaving an inert mineral dust (desertification).

Economic and population pressures on rural economies cause migration to the cities. This urbanisation leads to contamination of surface water and aquifers through poor sanitation, pollution of air, water and soil from vehicles, power plants and factories, and possibly to increased incidence of childhood diseases associated with heavy-metal poisoning (World Health Organisation, 1988; United States Geological Survey, 1984).

Mining has also caused contamination, including cyanide, mercury and arsenic releases from gold mining, and radioactiveelement pollution from tin mining. Large international mining companies now generally work to high environmental standards, but mineral working by uncontrolled and disorganised groups (especially for gold) continues to cause environmental problems in developing countries, as reported in recent incidents of mercury pollution in Brazil (Stigliani and Salomons, 1993).

\section{The surface environment in developing countries}

The socio-economic pressures on the environment in developing countries are frequently compounded by the susceptibility of the surface environment to degradation and pollution, especially in tropical climates. Some soils in these climates are deeply leached as a result of exposure to weathering during several millions of years, including long periods of high rainfall and temperature. Tropical soils thus tend to be poorer, thinner and more fragile than those in temperate regions (Murdoch, 1980). This is particularly so in shield areas of Africa and South America, where soils have developed on crystalline basement and are generally very old. In contrast, soils of south-east Asia developed on alluvium or volcanic rocks are generally younger and more fertile (McMichael, 1993).

In tropical countries of Africa, India, South America and Asia it is not uncommon to find laterites which have been forming continuously for 100 million years or more (since the Jurassic) (King, 1957; Michel, 1973). Weathering profiles may extend to depths of over $150 \mathrm{~m}$ (Trescases, 1992), so that the supply of chemical elements from bedrock to the biosphere is limited.

In such conditions, intense oxidation results in a lack of organic matter and of vital elements such as phosphorus, nitrogen and potassium, and in the formation of stable insoluble minerals such as clays (especially kaolinite). Generally, such soils are deficient in soluble cations (sodium and calcium) and anions (chloride, phosphate and nitrate), but have high levels of insoluble oxides of iron, aluminium, titanium and manganese. As natural vegetation is cleared from such environments, essential nutrients are further leached and the topsoil may be completely eroded away.

Some deserts were formerly subjected to extreme leaching under tropical conditions during the Cretaceous and Tertiary (Butt and Zeegers, 1992). Most desert soils are typically lithosols, the important constituents of which are detrital quartz, resistant minerals such as zircon, and secondary clay minerals. Organic material in desert soils is minimal, and surface waters are highly oxidising, with variable $\mathrm{pH}$ (frequently with high $\mathrm{pH}$ values). They generally have higher salinity than those in other environments, with chloride rather than bicarbonate as the main anionic species. Some generalised rela-

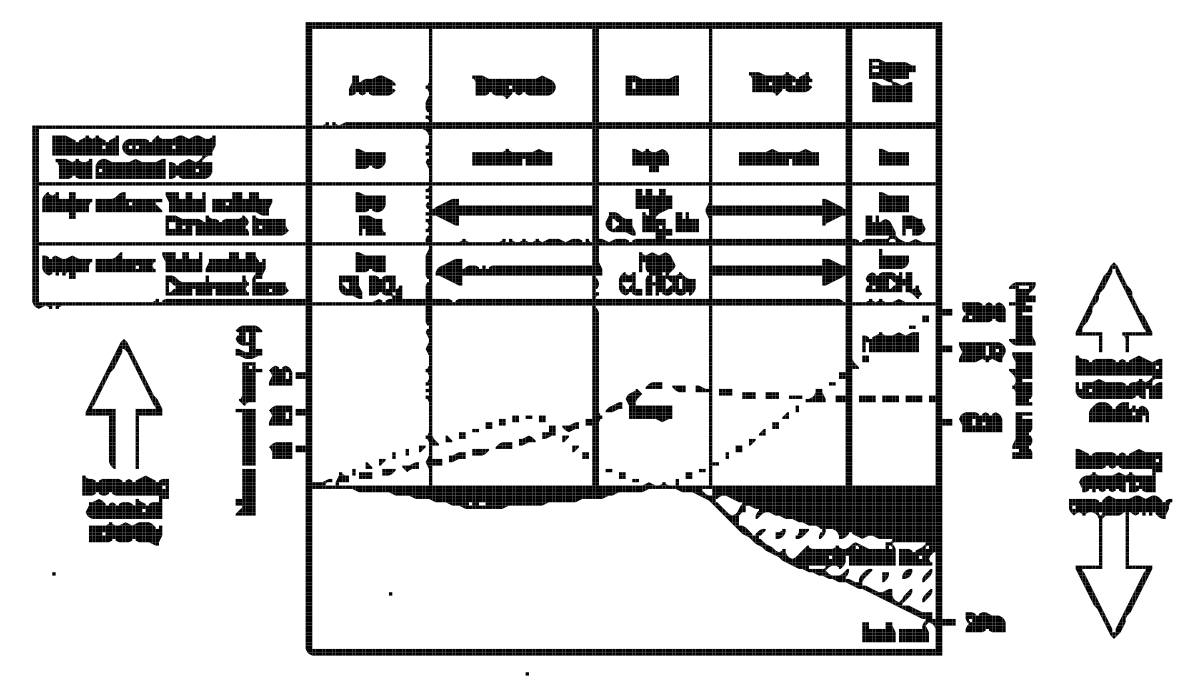

Figure 2 Generalised relationships between water chemistry and climatic and environmental factors (modified after Pedro, 1985). Differences in major-ion chemistry across these morphoclimatic environments strongly influence the abundance, mobility and environmental toxicity of potentially toxic elements during weathering. 
tionships between different surface environments are shown in Figure 2 .

Chemical elements tend to undergo more pronounced separation in tropical environments than in temperate regions (Trescases, 1992), so deficiency and toxicity conditions tend to be more common. The most deeply leached environments retain only the most inert elements such as iron, manganese, zirconium, hafnium and the rare earths, as secondary or primary oxides. The most mobile elements (alkalis, alkaline earths, halogens and elements mobile in conditions of high $\mathrm{pH}$, including anions and oxyanions, such as those of boron, selenium, molybdenum, vanadium and uranium) accumulate in arid environments generally, inland drainage systems and near the base of weathering profiles. The varied chemistry of the first-row transition elements cobalt, chromium, copper and zinc also favour removal from solution by ion exchange, precipitation and surface sorption. The lack of organic material as a result of intense oxidation can mean that total levels of such elements in the regolith may be high, but they may be bound on iron-manganese oxides and thus not be available for uptake by living matter, resulting in potential deficiency for plants and animals, especially in deeply oxidised surface environments. The controls on the chemical distribution of arsenic, cadmium and lead are broadly similar to those of the first-row transition metals (Ure and Davidson, 1995).

\section{Essential and potentially harmful chemical elements}

Two main groups of chemical elements are of particular importance for health. Those identified as essential to animal life (according to Mills, 1996) include the first-row transition elements (iron, manganese, nickel, copper, vanadium, zinc, cobalt and chromium) together with molybdenum, selenium, iodine and fluorine (Figure 1). The disorders associated with deficiency of these elements are given in Mills (1996). Boron has not yet been shown to be necessary for animals, although it is essential for higher plants. By contrast, PHEs known to have adverse physiological effects at relatively low levels include arsenic, cadmium, lead, mercury and some of the daughter products of uranium. Aluminium can also have adverse physiological effects in trace amounts in animals and particularly in fish and plants (Sposito, 1989). All trace elements are toxic if ingested or inhaled at sufficiently high levels for long enough periods of time. Selenium, fluorine and molybdenum show a narrow concentration range (of the order of a few $\mu \mathrm{g} / \mathrm{g}$ ) between essential and toxic levels.

The difficulties of diagnosing disease, and particularly subclinical conditions, related to trace-element deficiencies or excesses are discussed by Mills (1996). Except in some specific cases, for example Iodine Deficiency Disorders (IDD), symptoms may be non-specific and diagnosis, based on tissue or blood sampling, costly. Geochemical maps, however, can indicate areas where there is the potential for trace-element deficiency or toxicity, enabling expensive veterinary or medical investigations to be better targeted.

Geochemical surveys (ideally incorporating data for soil, stream-sediment and water samples) can also be of considerable value in studies linking diet and health. Although many PHEs, such as lead, are not poisonous to plants, elevated concentrations in the regolith may be transmitted into the food chain through uptake by healthy plants and can thus lead to adverse health effects in animals and humans, the source of which can be difficult to diagnose (Mills, 1996). The concentration of certain essential trace elements (such as selenium) in crops (rice, corn, soybean) has been shown to correlate with the concentrations in the soil in which they are grown (Levander, 1986); and, regionally, levels in fine-fraction stream sediments give a good indication of likely soil concentrations (Appleton and Greally, 1992). Geochemical mapping can therefore be a cost-effective method of indirectly investigating the chemical composition of crops. Rural communities in developing countries offer a particularly valuable opportunity for examining the relationship between geochemistry, diet and health.

\section{The need for baseline geochemical data in developing countries}

In many developed countries geochemical mapping is now an integral component of strategic systematic geoscience surveys (Plant and Hale, 1995; Plant et al., 1988; Darnley et al., 1995), with applications for a wide range of economic and environmental purposes (Webb, 1964; Thornton and Howarth, 1986; Thornton, 1983). An example from a recent hydrogeochemical survey of Wales, UK, is shown in Figure 3. It is clear from these studies that the distribution of trace elements in the surface environment can be difficult to deduce from geological maps (Darnley et al., 1995). Areas underlain by different granites, for example, may have similar major element concentrations but the levels of PHEs, such as uranium, molybdenum, beryllium and lead, can vary by factors of an order of magnitude or more (Plant et al., 1983). In tropical countries the problem is frequently compounded by deep weathering, whereby levels of chemical elements in the surface regolith may show little or no relationship to bedrock composition. Indeed, many elements, including aluminium, iron, manganese, cobalt, uranium, phosphorus, chromium, nickel, copper and gold, may be concentrated to ore grade in the lateritic mantle, and high concentrations of PHEs such as arsenic and antimony may also occur (Smith et al., 1987).

Geochemical mapping has long been used in combination with geological mapping as a mineral-exploration tool in developing countries. Regional geochemical maps, such as those of Zambia and Sierra Leone, were first published some 30 years ago (Webb et al., 1964; Nichol et al., 1966); and atlases, such as that of Uganda, more than 20 years ago (Reedman, 1973). Many of these surveys, however, covered only the regions considered most prospective for metalliferous mineral deposits, and were designed specifically to cover large areas at low density and cost (e.g. in Peru; Baldock, 1977).

More recent programmes, for example in Zimbabwe (Dunkley, 1987, 1988) and Sumatra (Stephenson et al., 1982; Coulson et al., 1988), have produced higher-density multi-element data with potential for application in environmental and animal and human health studies (Appleton and Ridgway, 1993). Basic hydrogeochemical parameters and data for such environmentally significant elements as selenium and iodine are generally lacking, however (Darnley et al., 1995).

There is now an urgent need in developing countries for highresolution geochemical data that is fully adequate for environmental and epidemiological studies, particularly in urban areas where conflicts between rapid development and environmental sustainability are severe and where surface water, groundwater and soils are increasingly becoming contaminated (World Health Organisation, 1988).

The requirements and methodologies for preparing high-resolution geochemical baseline data are discussed in detail in the final report of IGCP Project 259 (Darnley et al., 1995). This report includes internationally agreed standards for sampling, analysis and data processing in different terrains and recommends analytical methods for the most environmentally important elements, with limits of detection below crustal abundance. It also includes recommendations for a quality-control system and for databasing and presenting data.

At present no international agency is responsible for mapping the distribution of chemical substances, apart from radioactive elements for which the International Atomic Energy Agency provides the scientific infrastructure. Hence geochemical mapping tends to be carried out using a range of different methods, often varying according to short-term goals and the practices established in the developed country or organisation providing aid. Moreover, aid agencies often fund geochemical mapping only as a low-cost add-on to geological mapping for mineral exploration. This is unfortunate since geochemistry provides the most relevant geoscience data for environmental studies and land-use planning and has a much lower cost per 


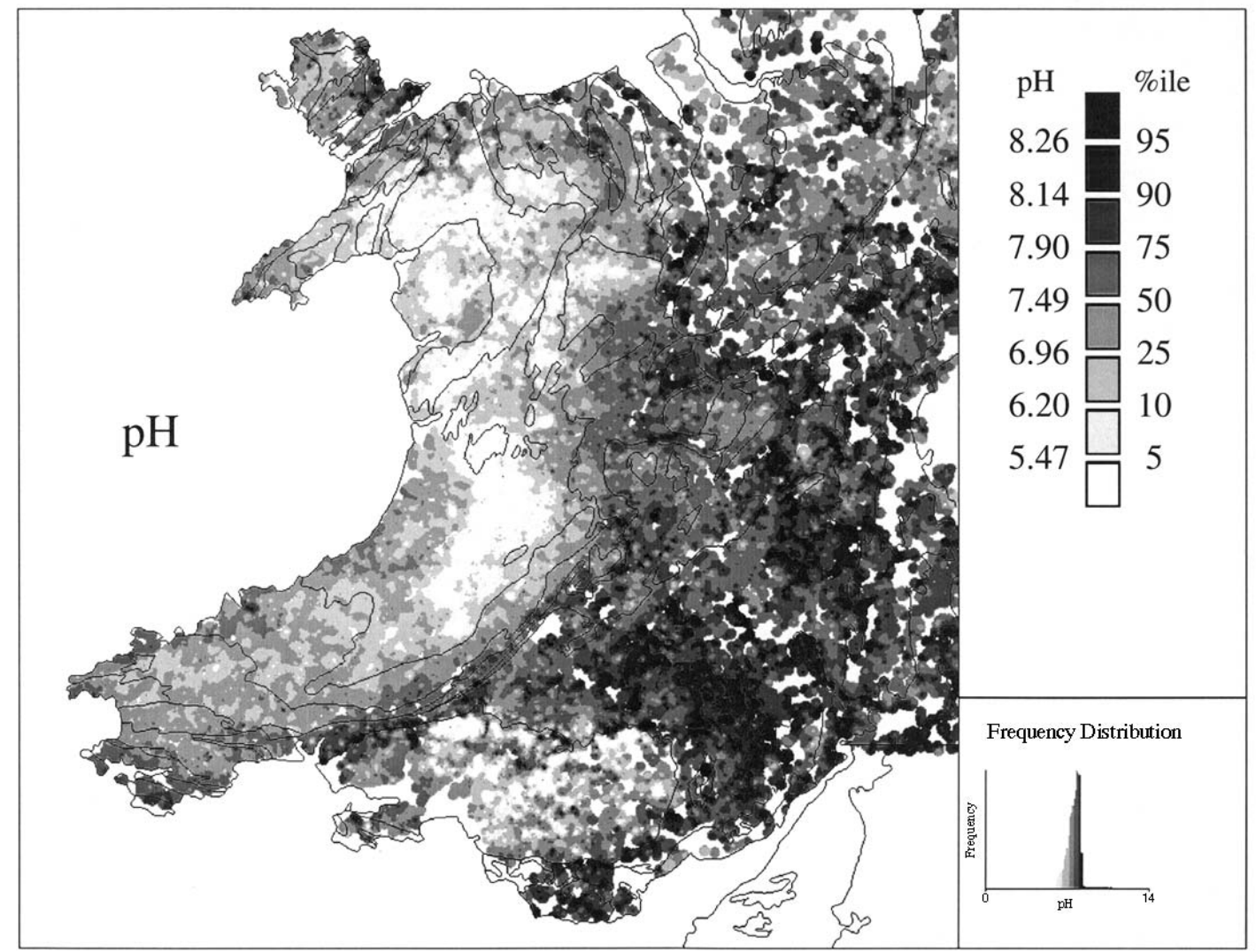

Figure 3 Map showing the $p H$ of over 13,000 stream-water samples in Wales and adjacent parts of England, measured during the course of the Geochemical Baseline Survey of the Environment $(G-B A S E)$ project of the British Geological Survey. The map clearly defines areas of acid stream water. Particularly noteworthy are acid waters resulting from former coal mining in South Wales, and basepoor waters over the uplands of North and midWales.

unit of area covered than other types of geoscience survey (Plant and Slater, 1986).

The separate conduct of surveys of the chemistry of soil, water and stream sediment by different agencies - a legacy from the time when geochemistry developed as a component of geological, soil and hydrological survey organisations - also limits the effective application of geochemistry in addressing environmental problems. Ideally, comparable data for each sample type should be collected as part of a single multi-media geochemical campaign. This is particularly important since new data on the behaviour of the chemical elements, combined with computer modelling and GIS, makes possible the preparation of geochemical maps targeted at environmental problems.

The recommendations of IGCP Project 259 (Darnley et al., 1995) have been taken forward by Project 360 and are now being set out in greater detail on a regional basis (e.g. Plant et al., in press, for Europe) coordinated by the IUGS/IAGC Working Group on Global Geochemical Baselines. Samples for a Global Reference Network are now being collected in many countries, and this sample set will be used to normalise existing data to a common standard for integration into a global geochemical atlas.

\section{Understanding the pathways of chemical elements from rocks and soils to man and animals}

The total concentration of chemical elements indicated on geochemical maps can be of direct value in studies of relationships between disease and the levels of trace elements (e.g. Appleton, 1992; Plant and Stevenson, 1985; Thornton and Plant, 1980; Plant and Thornton, 1986). However, the amount of each element which is available for uptake by living matter ('bioavailable') is more important for these studies than the total amount (e.g. Underwood, 1979). Aluminium, for example, the commonest metal in the earth's surface layer, occurs in both inert and bioavailable forms, and its potential toxicity thus depends on its chemical form ('speciation'). It can occur in a large number of dissolved species, especially in conditions of low or high $\mathrm{pH}$, or it can be hosted in colloids with organic carbon or silica which limit its toxicity.

The speciation of chemical elements affects their distribution, mobility and toxicity, and recent studies have shown that biochemical processes, induced by microbial, plant and animal activity, are important controls on speciation and mobility (Ehrlich, 1990; Deighton and Goodman, 1995).

Some of the most important controls, particularly on trace-element speciation and mobility, include hydrogen ion activity $(\mathrm{pH})$, redox potential (Eh), temperature, surface properties of solids, the abundance and speciation of potential ligands, major cations and anions, the presence or absence of dissolved and/or particulate organic matter, and biological activity. Two of the most important factors directly controlling mobility and solubility are Eh and $\mathrm{pH}$ (Figure 4). The solution chemistry of an element is affected profoundly by changes in oxidation state, while dissolution reactions, including hydrolysis, inorganic complexation, complexation with smaller organic anions (such as oxalate) and sorption/desorption, are all $\mathrm{pH}$ controlled. Under conditions of high $\mathrm{pH}$, anions and oxyanions (such as those of tellurium, selenium, molybdenum, uranium, arsenic, phosphorus and boron) are more mobile and most cations (such as those of copper, lead, mercury and cadmium) are less mobile, while at low $\mathrm{pH}$ the reverse is generally true. Where humic substances or biological byproducts are present, however, stable organo-metallic complexes (which may behave as anions) are formed, increasing trace-element mobility. The kinetics of interspecies interactions also act as important controls on speciation, particularly where natural systems are disturbed by human influence.

Geochemical interaction between the geosphere/hydrosphere and the biosphere depends partly on sorption processes and partly on chemical speciation. Some elements (e.g. aluminium, titanium and chromium) are poorly assimilated by plants, whereas others (e.g. cadmium, selenium, molybdenum and cobalt) can readily cross the soil-plant barrier and enter the food cycle (Loehr, 1987). In soils, sorption of elements by clay minerals and organic material is the predominant fixing mechanism, with soil $\mathrm{pH}$ controlling sorption pro- 


\begin{tabular}{|c|c|c|c|c|}
\hline \multirow{2}{*}{ FE_FInE } & \multicolumn{4}{|c|}{ 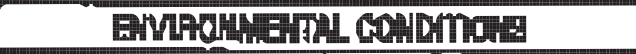 } \\
\hline & 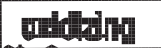 & a & 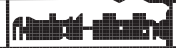 & 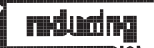 \\
\hline 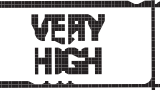 & I & $\|$ & 1 & 1 \\
\hline HeH & 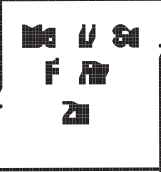 & 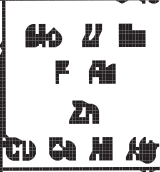 & F 䣲 & F $m$ \\
\hline MEEDHUIS & a cos & As $a$ & An & \\
\hline $\operatorname{Lan}$ & A & 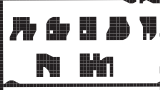 & 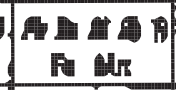 & $A \|$ \\
\hline 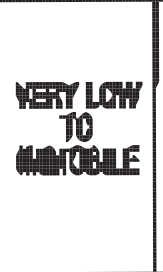 & 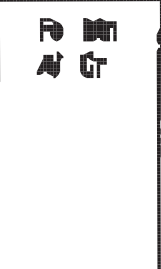 & 냄 & 告格 & 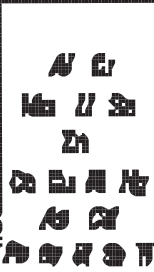 \\
\hline
\end{tabular}

Figure 4 General relationships between $\mathrm{Eh}, \mathrm{pH}$ and the mobility of some essential and potentially toxic elements (from Plant et al., 1996, modified after Andrews-Jones, 1968). Essential elements are shown in normal type and potentially hazardous elements in italics.

cesses and the solubility and bioavailability of each element. Many metals are more soluble in the low $\mathrm{pH}$ conditions induced by natural organic acids and root exudates.

In higher animals, including man, assimilation occurs by ingestion of nutrients and contaminants, by absorption through the skin, and by respiration (World Health Organisation, 1984). Speciation both in the natural environment and in the gastro-intestinal tract, exerts a major influence on the uptake and assimilation of trace nutrients and PHEs (World Health Organisation, 1984, 1994).

Speciation studies are of particular importance in areas affected by land degradation, deforestation or pollution caused by mining, industrial activity or urbanisation, where they can be used to optimise amelioration strategies and improve management practices. A knowledge of the factors controlling speciation in different environments can be used to estimate the potential for absorption of PHEs and as a guide to the need for trace-element supplementation for crops and animals, particularly where baseline geochemical data are available.

Ideally, environmental geochemical surveys, particularly in tropical terrain affected by intense chemical weathering, should be based on chemical speciation. Extraction techniques can be used to provide an indication of speciation (e.g. Tessier and Campbell, 1988), but sensitivity to changes prior to analysis limits the applicability of such determinations where large numbers of samples are involved.

Calculation of speciation using thermodynamic models such as WATEQ4F (Ball and Nordstrom, 1991), PHREEQE (Parkhurst et al., 1980) and EQ3/6 (Wolery, 1992) has greater potential, provided that suitable thermodynamic and/or kinetic data are available (Bassett and Melchior, 1990) and the effect of biochemical processes are quantified. An iterative approach using detailed experimental studies of selected elements to validate model calculations offers considerable potential for developing speciation maps from geochemical baseline data for large-scale environmental and epidemiological studies. Studies of aluminium and arsenic speciation, for example, are being used to develop methods of processing regional geochemical data to indicate speciation (Simpson et al., 1996; Smith et al., 1996).

\section{Selected case studies}

Three recent studies undertaken by the BGS illustrate the role of geochemistry in identifying, and in helping to ameliorate, environmental and health problems resulting from trace-element imbalances or contamination in developing countries.

\section{Natural trace-element imbalances and animal health}

Although undernutrition is the most important problem for livestock in tropical areas, trace-element deficiencies or imbalances in soils and forages are also responsible for low production and reproduction problems. For grazing livestock, deficiencies of cobalt, copper, iodine, iron, manganese, selenium and zinc, and excesses of copper, fluorine, manganese and molybdenum may lead to adverse effects; arsenic, lead, cadmium, mercury and aluminium also cause toxicity (Appleton, 1992).

The diagnosis and mapping of affected areas has generally been carried out using analysis of forage, animal tissue or fluid, which is expensive and time consuming (Appleton, 1992). Veterinary scientists and agronomists are generally familiar with the use of soil geochemistry, but the value of regional geochemical maps based on drainage samples is largely unknown, especially in developing countries (Appleton and Greally, 1992). Studies in Bolivia and Zimbabwe have been undertaken in order to assess whether such data, either collected specially or previously (e.g. for exploration), can be used to predict problems of animal health and whether low levels of trace elements in drainage sediments correlate with reported deficiencies in grazing livestock.

In northeastern Zimbabwe stream sediments, soils and forage all show similar regional patterns for zinc (Fordyce et al., 1996). The lack of a significant correlation between zinc levels in those media and the levels in cattle blood serum is ascribed in part to dietary and physiological factors. It is suggested that high concentrations of iron and manganese in soil and forage inhibit the availability and therefore the uptake of trace elements such as copper or zinc. Consequently, zinc levels in blood serum from cattle foraging in areas with

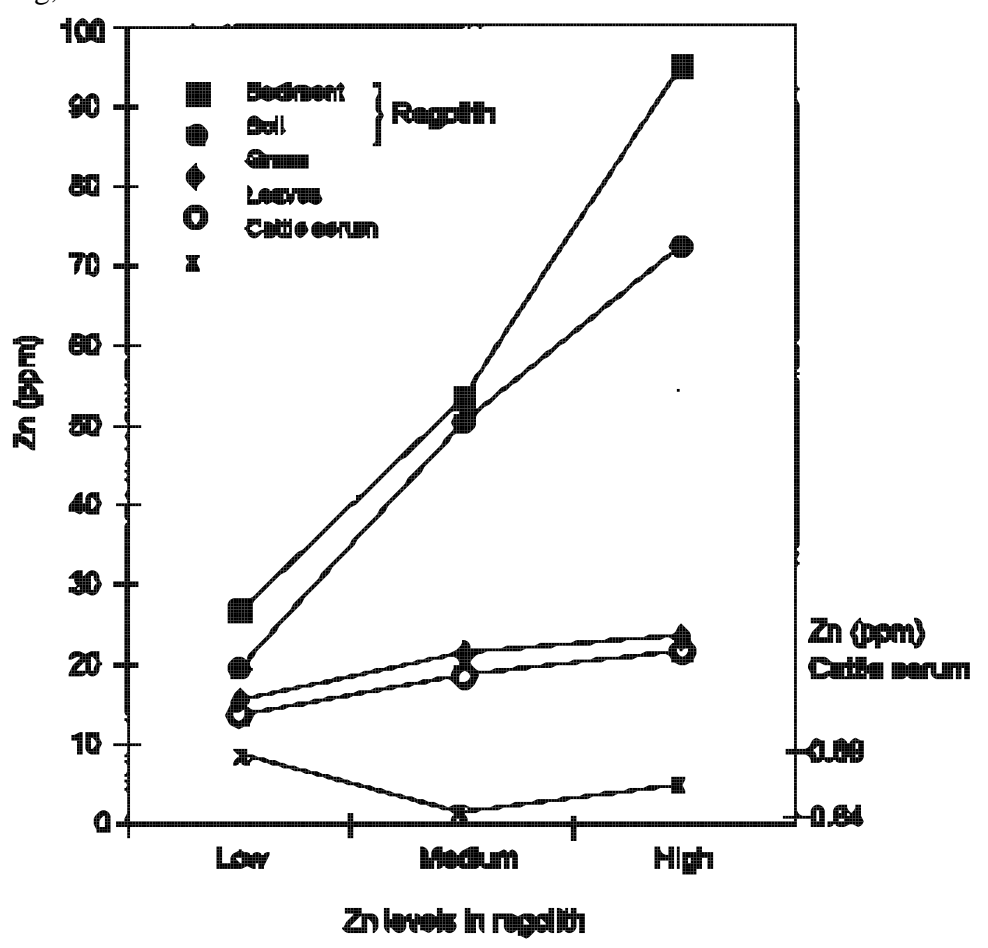

Figure 5 Zinc concentrations in stream sediment, soil, grass, leaves and cattle serum from northeast Zimbabwe (after Fordyce et al., 1996). 
moderate to high zinc levels may be as low as those from cattle feeding in low-zinc areas (Figure 5). Similarly, the availability of phosphorus to plants and animals may be significantly reduced by high levels of iron oxide in soils.

The study shows that regional stream-sediment geochemical data are of value in identifying areas where zinc and copper are likely to be deficient and areas where high iron and manganese may induce low zinc or copper status in cattle despite moderate to high levels of these trace elements in sediments, soils and forage.

This case study (Fordyce et al., 1996) therefore supports the review by McDowell et al. (1993) which identified a lack of direct correlation between trace-element levels in soil and forage and those in animal blood serum. The findings do not fully corroborate the conclusions of other reviews (Appleton, 1992; Thornton, 1983; Aggett et al., 1988) which suggest that stream-sediment geochemical maps can be used directly to indicate areas where ruminants may be subject to trace-element deficiencies. However, the conclusion that high concentrations of iron and manganese oxides in soil may inhibit the availability of phosphorus to plants and of copper and zinc to cattle could have wide implications in developing countries because of the preponderance of ferralitic soils in tropical regions. It also emphasizes the need to understand speciation or phase partitioning in order to relate total geochemical data to plant or animal health criteria.

\section{Environmental impact of coal-fired power stations}

Many developing countries depend heavily on coal-burning power stations for their energy supply, and these release into the environment large quantities of PHEs which are present at trace levels in the coal feedstock.

A comparison of the multi-element geochemistry of waste products and emissions at a power station in northeast China with that of the coal feedstock has shown that the combustion products are generally enriched by up to an order of magnitude (Simpson et al., 1995). The slag contains particularly high levels of beryllium, arsenic, molybdenum, cadmium and tungsten, while the fly-ash has high lithium, arsenic, cadmium, uranium and thorium. Mass-balance calculations (Figure 6) show that of the 36 tonnes per annum of arsenic consumed (6 ppm arsenic in 6 million tonnes of coal feed) some 24 tonnes are output in solid wastes (slag $12 \mathrm{ppm}$, and fly-ash

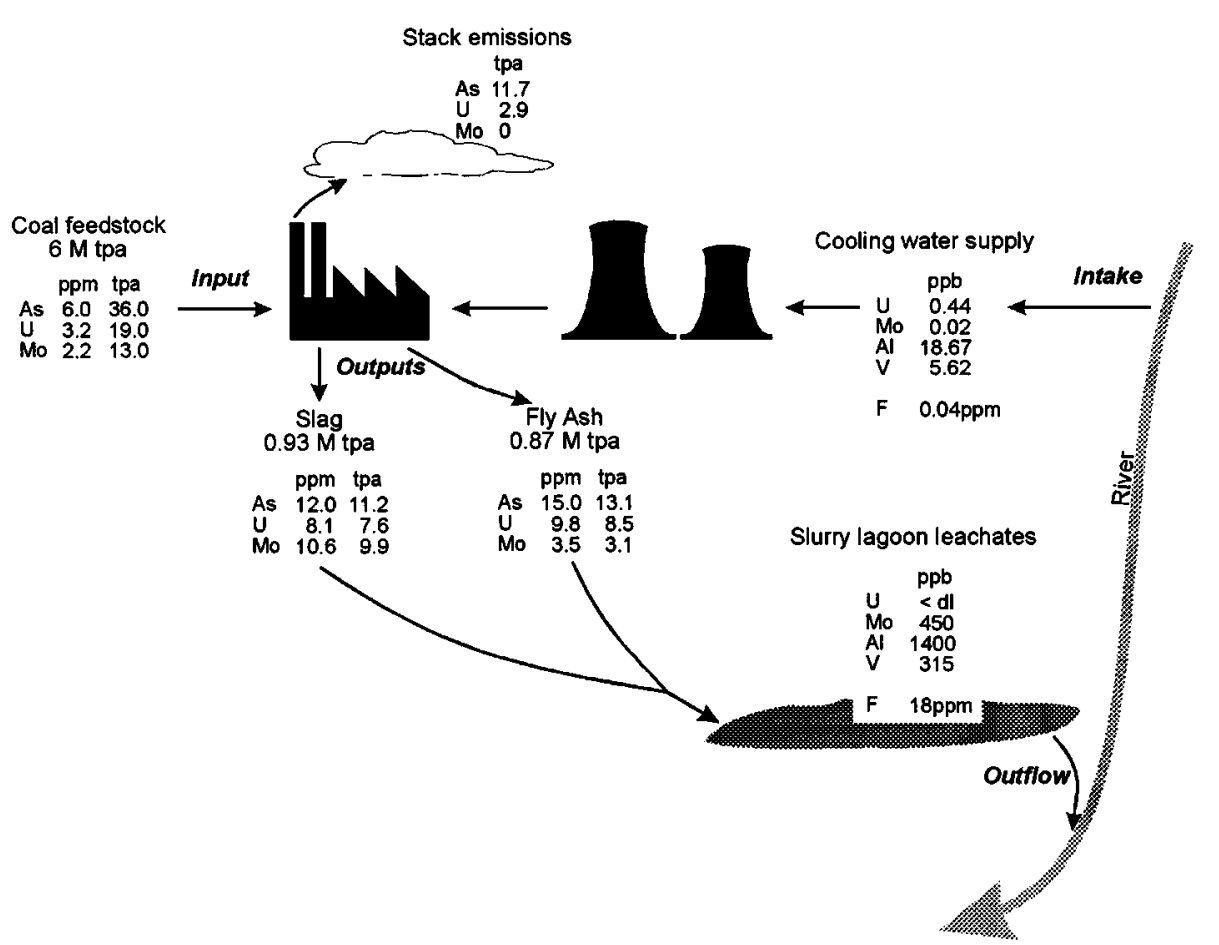

Figure 6 Mass balance calculations for some PHEs in a power station in northeast China (after Simpson et al., 1995).
$15 \mathrm{ppm}$ ), while almost 12 tonnes per annum of arsenic are emitted from the stack. By contrast, most uranium and all molybdenum are output in the solid wastes. The high levels of trace elements from stack emissions may have a considerable impact on the geochemistry of surface soils in the surrounding area. Such emissions could have adverse effects on the surface environment and on plant, animal or human health, especially if the PHEs occur as chemical forms that can be readily absorbed.

A further environmental hazard may result from leaching of PHEs from (often unlined) lagoons, in which slag and fly-ash slurries are dumped. A study of lagoon leachates (Simpson et al., 1995) shows that there is strong enrichment in some elements that can pose environmental threats, such as aluminium, molybdenum, vanadium and, particularly, fluorine, which exceeds $25 \mathrm{mg} / \mathrm{litre}$.

The surface environment around the power station has been geochemically characterised and compared with uncontaminated baseline regions of similar geology. Preliminary results confirm the importance of carbonate-rich rocks and well-buffered soils in reducing both the potential for acidification and the mobility of PHEs (Simpson et al., 1992; Flight, 1994).

\section{Impact of mining}

In many developing countries, the exploitation of mineral resources is of considerable importance for economic growth, employment and infrastructure development. It can also cause serious environmental problems, particularly in tropical regions characterised by high rates of weathering and biogeochemical cycling, because outputs of major constituents and impurities in the ore, or of chemicals used in processing, can accumulate to levels that may be harmful to plant, fish, animal and human health.

Studies of the environmental and health impacts of mining in southeast Asia and southern Africa have highlighted systematic relationships between mineral-deposit geochemistry, mining methods and drainage quality (Williams, 1993). The most important controls are water-rock interactions, sulphide oxidation rate at the fluid-rock interface and in-situ buffering which is strongly influenced by gangue mineralogy and weathering rate.

Mobilisation of most heavy metals is controlled by local $\mathrm{pH}$ and Eh conditions (Figure 4) and occurs principally at low $\mathrm{pH}$ under conditions of acid mine drainage. By contrast, arsenic is also mobile under alkaline conditions, a characteristic with important implications for remediation schemes because conventional buffering, such as liming, may be ineffective for arsenic-contaminated mine waters.

Iron oxyhydroxides in soils and stream sediments are very effective for scavenging and immobilising arsenic. Arsenic contamination of surface drainage, soil pore water and groundwater is therefore particularly serious in areas of low iron concentrations. In the neighbourhood of the Globe and Phoenix Mine in Zimbabwe, for example, soils with low $(<5 \%)$ iron content carry over $100 \mathrm{ppm}$ water-soluble arsenic, resulting in marked uptake by crops (up to $10 \mathrm{ppm}$ arsenic in maize), whereas no such enrichment occurs in vegetation over sites with similarly high total arsenic but with normal or high levels of iron, where the arsenic is held as immobile ferric hydroxide/arsenate complexes (Williams, 1994). The problem can be exacerbated by low soil phosphorus, as crops may assimilate arsenic as a phosphorus substitute, due to the close chemical similarity of the phosphate and arsenate anions 


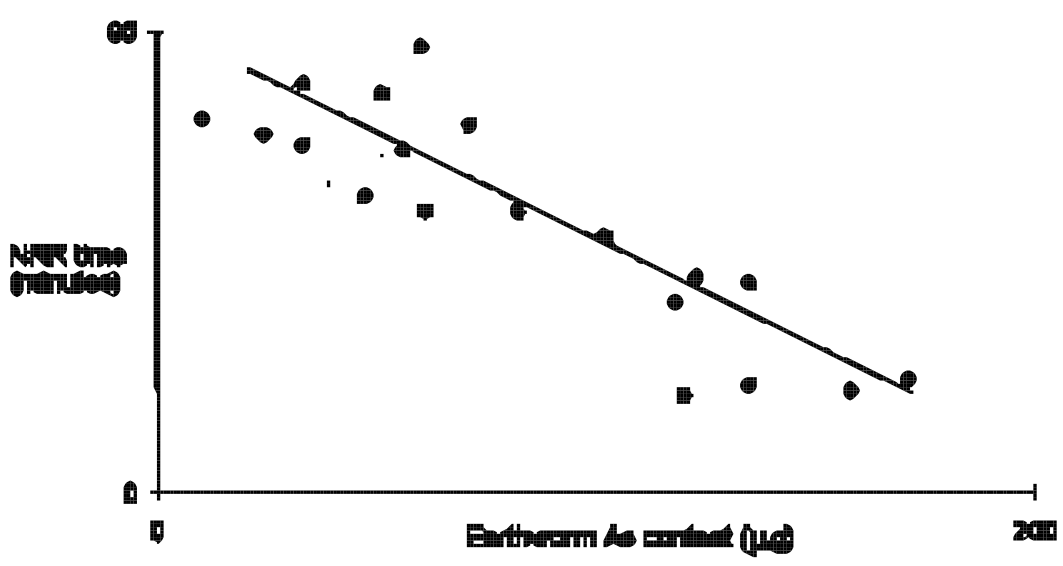

Figure 7 Results of neutral red retention (NRR) pilot test, Wanderer Mine, Zimbabwe (after Williams and Breward, 1995).

(Williams and Breward, 1995). In another example, in southern Thailand (National Epidemiological Board of Thailand, 1993), shallow groundwater exceeds $5 \mathrm{mg} / \mathrm{litre}$ arsenic (compared with the WHO drinking water guideline of only $10 \mu \mathrm{g} /$ litre) in areas where soils contain less than $2 \%$ iron. Where soil iron increases to more than $5 \%$, arsenic drops to $<100 \mu \mathrm{g} /$ litre (Fordyce and Williams, 1994). Modelling of iron-oxide sorption properties suggests that precipitation of dissolved iron as hydrous oxide would, in most conditions, scavenge arsenic effectively and may provide a practical remediation strategy for arsenic-rich mine waters by fixing the arsenic on inert solid materials.

Mining or beneficiation technology also has an effect on metal mobility. In the presence of cyanide complexing agents, the mobility of arsenic and heavy metals is maintained at neutral and even high $\mathrm{pH}$. Drainage waters of $\mathrm{pH} 8$, for example at Globe and Phoenix, can hold $>30 \mathrm{mg} /$ litre copper, $>10 \mathrm{mg} /$ litre arsenic and $>15 \mathrm{mg} / \mathrm{litre}$ antimony in the presence of cyanides, even at low $(<10 \mathrm{mg} / \mathrm{l})$ concentrations (Williams, 1994).

The effective assessment of the impact of mining contamination may be difficult and costly in developing countries. A practical, pioneering method has recently been developed and tested successfully at Wanderer Mine, Zimbabwe (Williams and Breward, 1995). Individual cells in earthworms are spiked with neutral-red dye. Healthy cells retain the dye for lengthy periods (>one hour) but with increasing exposure to toxic conditions (arsenic or heavy metals) the cells become stressed and release the dye increasingly rapidly (Figure 7).

\section{Conclusion and recommendations}

Recent advances in our understanding of the chemistry of natural systems, combined with improved computing power, analytical methods and information technology, now offer an opportunity for considerable advances in environmental geochemistry. New and sophisticated geochemical tools can be used as a basis for targeting resources into areas worst affected by environmental degradation and for identifying potential hazards and the factors that limit agricultural productivity or those likely to cause health problems in man. In order to benefit from these new approaches, more multi-element, multi-parameter baseline geochemical data are needed, as well as specific research into the behaviour of PHEs and essential nutrients in different geological and climatic terrains.

More work is needed on those trace elements that are essential to human health in small quantities but are harmful unless a critical, narrow range is maintained, especially selenium and iodine. Selenium deficiency has been linked to endemic osteo-arthropathic and cardiovascular disorders in parts of China (Tan, 1987), and to heart disease in Ohio (Schlamberger, 1980), while iodine deficiency disor- ders, including goitre and cretinism, are estimated to affect up to 800 million people in developing countries (World Health Organisation, 1994).

Inter-element effects also require more study. Until recently, high-quality geochemical data on elements such as selenium and iodine have rarely been available because of the difficulty or high cost of determining these elements at levels at and below the average abundance in natural materials. Analytical methods for selenium and for several other environmentally important chemical elements are now being developed by the BGS and other organisations to enable their distribution to be mapped cost effectively. Methods for studying the behaviour of aluminium and arsenic in the environment have also been developed. Studies of links between the distribution and chemical form of environmentally important elements and their epidemiological significance should now be pursued, ideally in countries with good epidemiological data, such as China (China Map Press, 1979).

Urbanisation is a major factor in the degradation of the natural environment, but there has been little or no systematic work on the sustainability of the geosphere and hydrosphere in the very large cities which are developing in the third world, or on their ability to absorb the effects of land degradation and pollution. Geochemical studies of the urban environment (including soil, water, dust and air) are urgently needed if the environmental damage caused by the rapid urbanisation of the developing world is to be contained, including the threats to the marine environment from major coastal cities.

Environmental geochemistry, particularly the preparation of high-quality baseline data (Darnley et al., 1995), has a crucial role to play in aiding the understanding of land-use problems and designing sustainable solutions appropriate for the economies of the developed and developing world. It is recommended that developing nations should prepare modern geochemical maps to the standards set out by IGCP Project 259, International Geochemical Mapping, now being coordinated by the IUGS/IAGC Working Group on Global Geochemical Baselines. Aid agencies should fund integrated environmental geochemical surveys, especially for health studies and landuse planning; particular attention should be paid to the environmental impact of urbanisation.

\section{Acknowledgements}

The paper is published by permission of the Director, British Geological Survey (NERC).

\section{References}

Aggett, P J, Mills, C F, Morrison, A, Callan, M, Plant, J A, Simpson, P R, Stevenson, A, Dingwall-Fordyce, I, and Halliday, C F, 1988, A study of environmental geochemistry and health in north-east Scotland, in Thornton, I, ed., Geochemistry and Health, Proceedings of the Second International Symposium: Northwood, Science Reviews Limited, pp. 81-91.

Andrews-Jones, D A, 1968, The application of geochemical techniques to mineral exploration: Colorado School of Mines, Mining Indust. Bull. 11, no. 6 .

Appleton, J D, 1992, Review of the use of regional geochemical maps for identifying areas where mineral deficiencies or excesses may affect cattle productivity in tropical countries: British Geological Survey Technical Report, no. WC/92/24.

Appleton, J D, and Greally, K, 1992, Environmental Geochemistry R\&D Project: A comparison of the trace element geochemistry of drainage sediments and soils in eastern Bolivia: British Geological Survey Technical Report, no. WC/92/67.

Appleton, J D, and Ridgway, J, 1993, Regional geochemical mapping in developing countries and its application to environmental studies: Applied Geochemistry, Supplement no. 2, pp. 103-110. 
Baldock, J W, 1977, Low density geochemical reconnaissance in Peru to delineate individual mineral deposits: Transactions of the Institution of Mining and Metallurgy (Section B, Applied earth science), v. 86, pp. B63-73.

Ball, J W, and Nordstrom, D K, 1991, Users manual for WATEQ4F with revised thermodynamic database and test cases for calculating speciation of major, trace and redox elements in natural waters: US Geological Survey Open-File Report, no. 91-183.

Bassett, R L, and Melchior, D C, 1990, Chemical modelling of aqueous systems: An overview, in Melchior, D C, and Bassett, R L, eds., Chemical Modelling of Aqueous Systems II: Washington DC, ACS Symposium Series, American Chemical Society, v. 416, pp. 1-14.

British Geological Survey, 1978-97, Regional geochemical atlas series: Keyworth, Nottingham, British Geological Survey.

Butt, C R M, and Zeegers, H, 1992, Climate, geomorphological environment and geochemical dispersion models, in Butt, C R M, and Zeegers, H, eds., Regolith Exploration Geochemistry in Tropical and Subtropical Terrains. Handbook of Exploration Geochemistry, Volume 4: Amsterdam, Elsevier, pp. 3-24.

China Map Press, 1979, Atlas of Cancer Mortality in the People's Republic of China: Shanghai.

Coulson, F I E, Peart, R J, and Johnson, C C. 1988, North Sumatra Geochemical and Mineral Exploration Project: Bandung, Direktorat Sumberdaya Mineral/British Geological Survey NSGMEP Report no. 25.

Darnley, A G, Björklund, A, Bølviken, B, Gustavsson, N, Koval, P, Plant, J A, Steenfelt, A, Tauchid, M, and Xuejing Xie, 1995, A Global Geochemical Database, Recommendations for International Geochemical Mapping, Final Report of ICGP Project 259: Paris, UNESCO.

Deighton, N, and Goodman, B A, 1995, The speciation of metals in biological systems, in Ure, A M, and Davidson, C M, eds., Chemical Speciation in the Environment: Blackie Academic and Professional, pp. 307-334.

Dunkley, P N, 1987, Regional drainage geochemical exploration survey of the country between Rushinga and Nyamapanda, NE Zimbabwe: British Geological Survey, Overseas Directorate, Report no. MP/87/16.

Dunkley, P N, 1988, Regional drainage geochemical exploration survey of the Harare area, Zimbabwe: British Geological Survey, Overseas Directorate, Report no. MP/87/18.

Ehrlich, H L, 1990, Geo-microbiology: New York, Marcel Dekker Inc.

Flight, D M A, 1994, Report on visit to Chongqing, Sichuan Province, P R China: British Geological Survey Technical Report no. WC/94/17R.

Fordyce, F M, Masara, D, and Appleton, J D, 1996, Stream sediment, soil and forage chemistry as indicators of cattle mineral status in northeast Zimbabwe, in Appleton, J D, Fuge, R and McCall, G J H, eds., Environmental Geochemistry and Health: Geological Society Special Publication no. 113, pp. 23-37.

Fordyce, F M, and Williams, T M, 1994, Impacts of mining and mineral processing with particular reference to gold and complex sulphide deposits: British Geological Survey Overseas Visit Report (unpublished).

King, L C, 1957, The geomorphology of Africa, in Erosion surfaces and their mode of origin: Science Progress, v. 45, pp. 672-681.

Levander, O A, 1986, Selenium, in Mertz, W, ed., Trace Elements in Human and Animal Nutrition, Fifth Edition, v. 2, pp. 209-279.

Loehr, R C, 1987, Advancing knowledge on protection of the land/soil resource: assimilative capacity for pollutants, in Draggan and others, eds., Geochemical and hydrologic processes and their protection: New York, Praeger.

Martyn, C N, Barker, D J P, Osmond, C, Harris, E C, Edwardson, J A, and Lacey, R F, 1989, Geographical relation between Alzheimer's disease and $\mathrm{Al}$ in drinking water: Lancet, v. 1, pp. 59-62.

McDowell, L R, Conrad, J H, and Hembry, F G, 1993, Minerals for Grazing Ruminants in Tropical Regions, Second Edition: University of Florida.

McMichael, A J, 1993, Planetary Overload. Global environmental change and the health of the human species: Cambridge University Press.

Mertz, W, ed., 1986, Trace Elements in Human and Animal Nutrition: Orlando, US Dept of Agriculture, Academic Press Inc.

Michel, P, 1973, Les Bassins des Fleuves Sénégal et Gambie. Etude Géomorphologique: Mémoire 63, ORSTOM, Paris, 752 pp.

Mills, C F, 1996, Geochemical aspects of the aetiology of trace element related diseases: A review of pathways of trace elements into the foodchain, in Appleton, J D, Fuge, R and McCall, G J H, eds, Environmental Geochemistry and Health: Geological Society Special Publication no. 113 , pp. $1-5$

Murdoch, W M, 1980, The Poverty of Nations, in The Political Economy of Hunger and Population: Baltimore, John Hopkins University Press, pp. 6-7.

National Epidemiological Board of Thailand, 1993, Arsenic contamination in Southern Province of Thailand: Information leaflet.
Nichol, I, James, L D, and Viewing, K A, 1966, Regional geochemical reconnaissance in Sierra Leone: Transactions of the Institution of Mining and Metallurgy (Section B: Applied earth science), v. 75, pp. B146-161.

Parkhurst, D L, Thorstenson, D C, and Plummer, L N, 1980, PHREEQE - A computer Program for geochemical calculations: US Geological Survey, Water Resources Investigation Paper no. 80-96, 210pp.

Pedro, G, 1985, Grandes tendances des sols mondiaux: Cultivar, v. 184, 78-81 [in French].

Plant, J A, Baldock, J W, and Smith, B, 1996, The role of geochemistry in environmental and epidemiological studies in developing countries: a review, in Appleton, J D, Fuge, R, and McCall, G J H, eds., Environmental Geochemistry and Health: Geological Society Special Publication no. 113 , pp. 7-22.

Plant, J A, and Hale, M, eds., 1995, Handbook of Exploration Geochemistry, Volume 6, Drainage Geochemistry: Amsterdam, Elsevier.

Plant, J A, Hale, M, and Ridgway, J, 1988, Developments in regional geochemistry for mineral exploration: Transactions of the Institution of Mining and Metallurgy (Section B: Applied earth science), v. 97, pp. B116-140.

Plant, J A, Klaver, G, Locutura, J, Salminen, R, Vrana, K, and Fordyce, F M, In press, The Forum of European Geological Surveys Geochemistry Task Group: Geochemical inventory: Journal of Geochemical Exploration.

Plant, J A, Simpson, P R, Green, P M, Watson, J V, and Fowler, M B, 1983, Metalliferous and mineralised Caledonian granites in relation to regional metamorphism and fracture systems in northern Scotland: Transactions of the Institution of Mining and Metallurgy (Section B: Applied earth science), v. 92, pp. B33-42.

Plant, J A, and Slater, D, 1986, Regional geochemistry — potential developments: Transactions of the Institution of Mining and Metallurgy (Section B: Applied earth science), v. 95, pp. B63-70.

Plant, J A, and Stevenson, A G, 1985, Regional geochemistry and its role in epidemiological studies, in Mills, C F, Bremner, I, and Chesters, J K, eds., Trace Element Metabolism in Man and Animals: Aberdeen, Rowett Research Institute, pp. 900-906.

Plant, J A, and Thornton, I, 1986, Geochemistry and health in the United Kingdom, in Thornton, I, ed., Proceedings of the First International Symposium on Geochemistry and Health: Northwood, Science Reviews Ltd, pp. 5-15.

Reedman, A J, 1973, Geological atlas of Uganda: Entebbe, Uganda Geological Survey and Mines Department.

Schlamberger, R J, 1980, Selenium in drinking water and cardiovascular disease: Journal of Environmental Pathology and Toxicology, v. 4-2, pt 3, pp. 305-308

Simpson, P R, Breward, N, Cook, J M, Flight, D M A, Hall, G E M, Lister, T R, and Smith, B, 1996, High resolution regional hydrochemical mapping of stream water for mineral exploration and environmental studies in Wales and the Welsh borders: Applied Geochemistry, v. 11, pp. 621-632.

Simpson, P R, Flight, D M A, and Bull, K, in collaboration with Zeng Rongshu, Zhang Yi-Gang, and Xu Wen-Long, 1992, Report on visit to Tangshan General Power Plant, Tangshan, Hebei Province, P R China: British Geological Survey Technical Report no. WC/92/49R.

Simpson, P R, and 14 others, 1995, Environmental impact of coal-burning power stations. British Geological Survey Technical Report no. WC/95/44.

Smith, B, Breward, N, Crawford, M B, Galimaka, D, Mushiri, S M, and Reeder, S, 1996, The environmental geochemistry of aluminium in tropical terrains and its implications to health, in Appleton, J D, Fuge, R, and McCall, G J H, eds., Environmental Geochemistry and Health: Geological Society Special Publication No. 113, pp. 141-152.

Smith, R E, Birrell, R D, and Brigden, J, 1987, The implication to exploration of chalcophile corridors in the Archaean Yilgarn Blocks, Western Australia, as revealed by laterite geochemistry, in Programme and Abstracts, 12th International Geochemical Exploration Symposium: Orleans, BRGM, 76 pp.

Sposito, G, 1989, The Environmental Chemistry of Aluminium: Boca Raton, Florida, CRC Press.

Stephenson, B, Ghazali, S A, and Widjaja, H, 1982, Regional geochemical atlas of Northern Sumatra: Institute of Geological Sciences.

Stigliani, W, and Salomons, W, 1993, Our fathers' toxic sins: New Scientist, December 1993, pp. 38-42.

Tan Jianan, 1987, The influence of selenium deficiency in the environment on human health in NE China, in, J Lag, ed., Excess and deficiency of trace elements in relation to human and animal health in Arctic and SubArctic regions, pp. 90-108.

Tessier, A, and Campbell, P G C, 1988, Partitioning of Trace Elements in Sediments, in Proceedings, Metal Speciation Theory, Analysis and Application: Lewis Publishers Inc., pp. 183-199. 
Thornton, I, ed., 1983, Applied Environmental Geochemistry: London, Academic Press, 501 pp.

Thornton, I, and Howarth, R J, eds., 1986, Applied Geochemistry in the 1980s: London, Graham and Trotman.

Thornton, I, and Plant, J A, 1980, Regional geochemical mapping and health in the United Kingdom: Journal of the Geological Society of London, v. 137, 575-586.

Trescases, J J, 1992, Chemical weathering, in Butt, C R M, and Zeegers, H, eds., Regolith Exploration Geochemistry in Tropical and Subtropical Terrains. Handbook of Geochemistry, Volume 4, pp. 25-40.

Underwood, E J, 1979, Trace elements and health: an overview: Philosophical Transactions of the Royal Society of London, v. B288, pp. 5-14.

United Nations Department of International Economic and Social Affairs, 1992, Long Range World Population Projections: New York, United Nations.

United States Geological Survey, 1984, Water Quality Issues in National Water Summary 1983, Hydrologic Events and Issues: Water Supply Paper 2250, Washington DC.

Ure, A M, and Davidson, C M, eds., 1995, Chemical Speciation in the Environment: Blackie Academic and Professional.

Webb, J S, 1964, Geochemistry and life: New Scientist, v. 23, pp. 504-507.

Webb, J S, Fortescue, J A C, Nichol, I, and Tooms, J S, 1964, Regional geochemical maps of the Namwala Concession area, Zambia, nos 1-X: Lusaka, Geological Survey.

Williams, T M, 1993, Dispersal pathways of arsenic and mercury associated with gold mining and mineral processing. Field visit to Zimbabwe: British Geological Survey Technical Report no. WP/93/7R.

Williams, T M, 1994, Impacts of mining and mineral processing with particular reference to gold and complex sulphide deposits and environmental geochemical mapping. Field visit to Zimbabwe: British Geological Survey Technical Report no. WP/94/4.

Williams, T M, and Breward, N, 1995, Environmental impact of gold and complex sulphide mining (with particular reference to arsenic contamination): British Geological Survey Technical Report no. WC/95/2.

Wolery, T J, 1992, EQ3/6: Version 7,. A software package for geochemical modelling of aqueous systems: Lawrence Lovermoor National Laboratory, Report no. UCRL:MA-110662, pts 1, 2 and 3.

World Bank, 1992, World Development Report: Development and the Environment: Oxford, Oxford University Press.

World Health Organisation, 1984, Guidelines for Drinking Water Quality: Volume 2, Health Criteria and Other Supporting Information: Geneva, World Health Organisation.

World Health Organisation, 1988, Urbanisation and its implications for child health: potential for action: Geneva, World Health Organisation.

World Health Organisation, 1994, World Health Organisation Report Series: Environmental Health Criteria: Geneva, World Health Organisation.

Professor J A Plant CBE is Assistant Director and Head of the Minerals, Environment \& Geochemical Surveys Division of the British Geological Survey, and has been responsible for the systematic regional geochemical survey of Great Britain since 1975. She is a graduate of the University of Liverpool, where she is now visiting professor, and was Distinguished Lecturer for the Association of Exploration Geochemists in 1992-1994. She was chairman of the FOREGS (Forum of European Geological Surveys) Geochemistry Task Group, 1994-1996, and is currently co-chairman of the IUGS/ IAGC Working Group on Global Geochemical Baselines.
Dr J W Baldock is Head of the Analytical \& Regional Geochemistry Group of the BGS and has been responsible for geochemical exploration and geological mapping programmes both overseas and in the UK. He is a graduate of Cambridge University, with a doctorate from the University of Leeds, and joined the BGS in 1967. He has worked extensively in developing countries in Africa and Latin America. He has recently been involved in managing BGS's environmental geochemistry programmes, especially in relation to environmental impacts and human health.

Dr $\boldsymbol{H} \boldsymbol{W}$ Haslam is a graduate of the University of Cambridge, where he also obtained his doctorate. He has worked for the BGS since 1968, in the UK and overseas, and has undertaken investigations in geochemistry, mineralogy, and mineral exploration. He has been much involved in editorial work, including responsibility for recent volumes of the BGS regional geochemical atlas series.

Dr B Smith is a graduate of the University of Bath. He is a Chartered Chemist and since joining BGS in 1987 has undertaken investigations in the fields of waste disposal, environmental geochemistry and health, and regional geochemical mapping. His current research interests focus on the use of geochemical baseline information in RISK assessment. These studies and his interests in geochemistry, and the applications of geoscience to environmental management have taken him to developing countries in Africa and the Middle East.
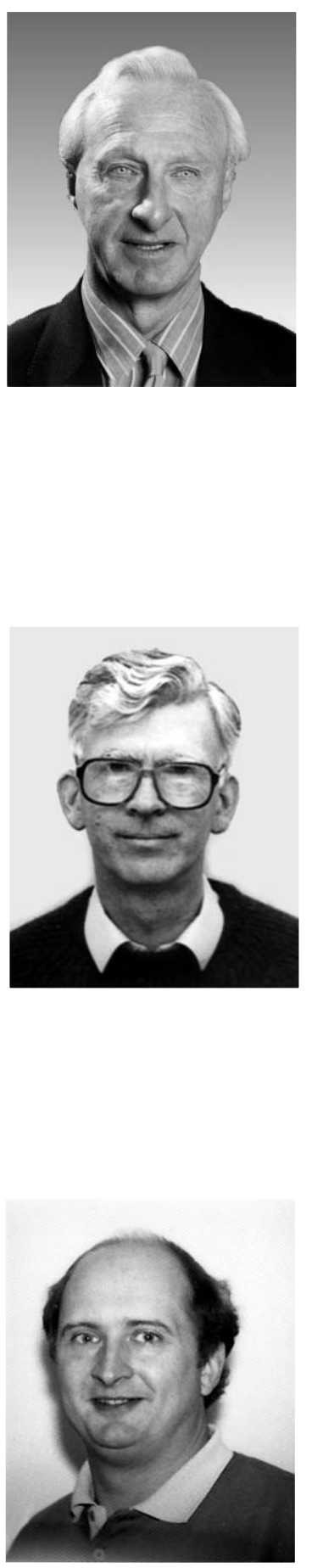